Михайльова, К., Шкурапет, Н. (2020). Потенціал використання понять «спосіб життя» та «стиль життя» для соціологічного аналізу практик щодо індивідуального здоров'я. Соиіологічні студї, 1 (16), 64-74. DOI: https://doi.org/10.29038/2306-3971-2020-01-64-74

\title{
Потенціал використання понять «спосіб життя» та «стиль життя» для соціологічного аналізу практик шодо індивідуального здоров'я
}

\author{
Катерина Михайльова - \\ доктор сочіологічних наук, \\ професор, проректор \\ з науково-педагогічної \\ та навчально-методичної \\ роботи, Харківський гуманітарний \\ університет «Народна українська \\ академія», Харків, Украӥна
}

\section{Kateryna Mykhaylyova -}

Doctor of Sociology, Professor, Vice-rector for methodical and education work, Kharkov University of Humanities "People's Ukrainian Academy», Kharkiv, Ukraine Email: emihaileva@gmail.com ORCID: https://orcid.org/0000-00034152-0654

\author{
Наталія Шкурапет - \\ аспірантка кафедри соиіологї, \\ Харківський гуманітарний \\ університет «Народна украӥнська \\ академія», Харків, Украӥна
}

\section{Nataliya Shkurapet -}

Phd student, Department of Sociology, Kharkov University of Humanities "People's Ukrainian Academy», Kharkiv, Ukraine.

Email: director@gymn14.net ORCID: https://orcid.org/0000-00020309-8838

DOI: https://doi.org/10.29038/23063971-2020-01-64-74

Reseived: March, 2020

$1^{\text {st }}$ Revision: March, 2020

Accepted: April, 2020
У статті розглянуто теоретичні основи досліджень феноменів способу життя та стилю життя. Здійснено ретроспективний аналіз підходів до їх трактування. Показано, що основними маркерами способу життя є види життєдіяльності й способи їх реалізації, що нормуються соціально-політичними, культурними або соціальноекономічними конструкціями в суспільстві. Продемонстровано, що спосіб життя відбиває соціально типові практики. Стиль життя $є$ більш індивідуалізованим феноменом, який має особливі прояви в повсякденному житті та вбудовується в соціальний простір кожним індивідом або групою. На основі різноманітних визначень цих понять здійснено їх порівняння. Розглянуто можливості використання зазначених категорій для аналізу феномену індивідуального здоров'я. На основі врахування його особливостей зроблено висновок про превалювання застосування поняття «здоровий спосіб життя» над терміном «здоровий стиль життя». Підкреслено, що їх розмежування може здійснюватися залежно від концепції дослідження 3 урахуванням континуумів «норма-варіативність», «соціальнеіндивідуальне».

Mykhaylyova Kateryna, Shkurapet Nataliya. The Potential of Using the Concepts «Way of Living» and «Life Style» for Sociological Analysis of Individual Health Practices. The theoretical bases of the analysis of the phenomena «way of living» and «lifestyle» are considered in the article. The retrospective analysis of approaches to its consideration is made. It is shown that the main markers of way of living are the types of life activity and ways of its implementation, which are normalized by socio-political, cultural or socio-economic structures in society. It has been demonstrated that way of living reflects socially typical practices. Lifestyle is a more individualized phenomenon that has particular manifestations in everyday life and is embedded in the social space by each individual or group. All approaches to the interpretation of way of living and lifestyles are grouped into three groups: a synonymous approach 
in which the terms «way of living» and «lifestyle» are regarded as interchangeable; an approach in which lifestyle is viewed as a narrower concept than way of living; an approach where these concepts are differentiated and treated as equivalent. On the basis of various definitions of these concepts, their comparison was made and a conclusion about the substantive sub-catherogality of the concept of «lifestyle» with respect to the concept of «way of living» was made. Possibilities of using these categories to analyze the phenomenon of individual health are considered. The necessity of the multidisciplinary nature of using of the concepts of «way of living» and «lifestyle» in its research is shown. Based on its features, it is concluded that the using of the concept of «healthy way of living» over the concept of «healthy lifestyle». The second is considered as an individualized version of the first. It is shown that the use of one of the studied concepts does not limit the possibility of using another. Their differentiation can be made depending on the concept of the research taking into account the continuums: «norm - variability», «social - individual».

Key words: way of living, lifestyle, healthy way of living, social practices, individual health.

Михайлева Екатерина, Шкурапет Наталья. Потенциал использования понятий «образ жизни» и «стиль жизни» для социологического анализа практик в отношении индивидуального здоровья. В статье рассматриваются теоретические основы исследования феноменов «образ жизни» и «стиль жизни». Осуществляется ретроспективный анализ подходов к их трактовке. Показывается, что основными маркерами образа жизни выступают виды жизнедеятельности и способы их осуществления, которые нормируются социально-политическими, культурными или социально-экономическими конструкциями в обществе. Демонстрируется, что образ жизни отражает социально типичные практики. Стиль жизни является более индивидуализированным феноменом, который имеет особые проявления в повседневной жизни и встраивается в социальное пространство каждым индивидом или группой. На основе различных определений этих терминов осуществляется их сравнение. Рассматриваются возможности использования указанных категорий для анализа феномена индивидуального здоровья. На основе учета его особенностей делается вывод о превалировании использования понятия «здоровый образ жизни» над термином «здоровый стиль жизни». Подчеркивается, что их разграничение может осуществляться в зависимости от концепции исследования с учетом континуумов «норма-вариативность», «социальное-индивидуальное».

Ключевые слова: образ жизни, стиль жизни, здоровый образ жизни, социальные практики, индивидуальное здоровье.

Постановка проблеми. В умовах сучасних соціальних змін, динамічних перетворень в усіх сферах життєдіяльності суспільства питання здоров'я та факторів впливу на нього стає все більш актуальним. Стан постійних змін впливає на сучасну людину, вимагаючи від неї гнучкості, високого рівня адаптивності. За таких умовах зростає і фізичне, і психологічне навантаження на людину, змінюючи спосіб іiі життя.

Цей процес відбувається у двох напрямах: з одного боку, розвиток технологій, спрямований на полегшення й оптимізацію життєдіяльності сучасної людини, а здоров'я декларується як важливий ресурс та маркер іiі ефективності; з іншого - технологічне різноманіття й високий динамізм соціального життя сприяють інтенсивному зануренню особистості в інформаційно-комунікаційне технологічне середовище, котре стає його повсякденністю та призводить до перевантаження людини, що не сприяє відновленню потенціалу організму, збереженню її здоров'я,

Конструювання власного способу життя особи, у тому числі й щодо здоров'я, залежить від сукупності факторів, аналіз яких може дати відповіді на питання, пов'язані з можливими впливами на ці процеси. За даними ВООЗ, на 50 \% здоров'я визначається соціально-економічними умовами, на $20 \%$ - екологічними, такою ж мірою - спадкоємністю та на $10 \%$ - організацією охорони здоров'я та якістю медичних послуг (WHO strategy). Аналіз впливу зазначених вище факторів на індивідуальному рівні крізь призму чинників, які $є$ залежними/незалежними від особистості, дають підставу дослідникам протягом останніх десятиліть стверджувати, що індивідуальне здоров'я людини на 5055 \% залежить від способу життя (Журавлева, 2002; Лисицин, 1982; Парфенова, Проскурнина, Цой; Яковлева, 2013). Отже, спосіб життя постає одним із важливих факторів, котрий визначає стан здоров'я людини. Водночас підкреслимо, що в сучасному суспільстві формуються різноманітні способи життя, які безпосередньо інтегрують у собі практики щодо власного здоров'я.

Поряд 3 об'єктивними детермінантами здоров'я та способом життя людини існують також індивідуалізовані чинники, пов'язані 3 особистими цінностями, настановами, баченням власних життєвих цілей і засобів їх досягнення. Це актуалізує питання впливу стилю життя на практики власного здоров'я. 
Відповідно, різноманітність стилів життя в умовах глобалізації демонструє варіативність у сучасному світі, зокрема щодо стратегій стосовно власного здоров'я. Тобто сьогодні простежено значні можливості: інформаційні, технологічні, комунікативні, - які мають потенціал для формування основ здоров'я й засобів його підтримки та збереження. Але, за даними ВОЗ, лише незначна частина населення реалізовує його.

Отже, як спосіб, так і стиль життя стають важливими для забезпечення здоров'я людини, надаючи особливостей засобам організації та реалізації практик щодо індивідуального здоров'я. Але відкритим залишається питання, у яких аспектах дослідження цієї діяльності актуальним є потенціал «способу життя», а в яких - «стилю життя».

Аналіз останніх досліджень і публікацій. У вітчизняній та зарубіжній літературі достатньо уваги приділено феноменам способу й стилю життя. Ці питання розробляли такі вчені-класики, як К. Маркс, М. Вебер, Т. Веблен, У. Уорнер, П. Бурдьє та ін. Сучасних аспектів розгляду способу життя стосуються роботи Е. Вайнера, С. Костюріна, Ю. Лисицина, О. Мурадян, О. Федько й ін. Стиль життя став об’єктом наукових досліджень Н. Масленцевої, Я. Рощиної, А. Сафарян, Т. Пилаєвої та ін. Зберігають актуальність у цьому колі досліджень і наукові розвідки Н. Паніної.

Завдяки цим працям розкривається сутність понять «спосіб життя» та «стиль життя»; особливу увагу приділено факторам впливу на ці феномени, зокрема запропоновано розглядати їх за рівнями: макро-, мезо-, мікро-, - а також крізь призму об'єктивного й суб'єктивного. Такі структурно-функціональні акценти, на наш погляд, є важливими для дослідження практик щодо індивідуального здоров'я та становитимуть методологію нашого аналізу.

Окрему увагу в наукових працях приділено питанням здорового способу життя. Так, у роботах М. Віленського, К. Логачової, У. Кокерхейма, О. Пахолок, Є. Вайнера розкрито сутність цього феномену, визначено його ключові маркери.

Водночас треба підкреслити, що в науковому полі досі тривають дискусії щодо співвіднесення понять «спосіб життя» й «стиль життя» та коректності їх потенціалу для застосування в контексті практик стосовно власного здоров’я людини.

Мета статті. Наявність соціальної проблеми й обмеженість наявних теоретичних відповідей для iii розв’ язання визначають мету статті - проведення соціологічного аналізу понять «спосіб життя» та «стиль життя» й демонстрація їхньої можливості під час дослідження індивідуального здоров’я людини.

Виклад основного матеріалу. Поняття «спосіб життя» введено в науковий обіг К. Марксом та Ф. Енгельсом. Так, у їхніх наукових працях спосіб життя потрактовано як спосіб спільного створення людьми умов власного життя, який здійснюється в конкретно-історичній системі суспільних відносин (Маркс, Енгельс, 1955). Зважаючи на це, можемо стверджувати, що 3 початку досліджень феномену «спосіб життя» увагу зосереджено на його соціальних детермінантах і певній активності соціальних суб’єктів.

Значну кількість досліджень способу життя проведено радянськими соціологами в 60-80-ті рр. ХХ ст. в межах структурно-функціональної концепції способу життя, що характерно для суспільства того часу (див. Советский образ жизни, 1984; Возьмитель, 2017).

Спроби розкрити конкретні механізми взаємодії людей між собою й умовами, що оточують їх, організації людьми своєї повсякденної життєдіяльності, їі вписування в ширші соціокультурні контексти здійснено в ситуативній концепції «способу життя», яка розроблена в середині 80-х років минулого століття, але так і не стала реалізованою.

За часів пострадянського суспільства відбувся перехід до динамічної концепції способу життя, що пов'язано з появою нових соціальних практик та потребою, відповідно до цього пошуку нових методологічних підходів до їх вивчення. Основні принципи цієї концепції сформульовано А. Возьмителем:

- «саме відмінності в життєдіяльності людей, а не їх належність до тієї чи іншої багато в чому формальної соціостатусної групи - суть головного критерію диференціації та типологізації способу життя, а також виокремлення його суб'єктів;

- у центрі суб'єктно-діяльнісного підходу - особистість, яка діє в різних масштабах свого життя і яка саме в результаті певної діяльності набуває статусу ії суб'єкта й віднесена нами до того чи іншого соціального чи соціально-психологічного типу, продукуючого цілком певний спосіб або стиль життя; 
- спосіб життя не є чимось статичним. Це процес як свідомий, так і стихійний. Свідомий тому, що люди самі вибирають моделі життєдіяльності, а то й творять у них, стихійний - у тому плані, що результат конкуренції цих моделей далеко не завжди передбачуваний. Взаємодіючи між собою, утворюючи стійкі поєднання конкретних типів життєдіяльності, вони формують цілком певні домінантні, емпірично фіксовані риси особистості, сім'ї, мотивації, праці, зразки самоідентифікації, сприйняття та ставлення до світу, із яких викристалізовується реальний спосіб життя суспільства в цілому» (Возьмитель, 2012, с. 29-30).

Отже, у такій конотації категорію «спосіб життя» розглядаємо як «результат взаємодії (а нерідко - i боротьби) домінувальних способів та стилів життя, що продукують особистості певних соціальних типів» (Возьмитель, 2012, с. 31). І вже на цьому етапі стають актуальними питання співвідношення «соціально організованих» та «індивідуалізованих» маркерів способів життя, які, на нашу думку, можуть бути застосовані під час дослідження соціальних практик стосовно власного здоров'я людини.

Без сумніву, у науковій літературі існують різноманітні підходи до визначення поняття «спосіб життя», під час аналізу котрих можемо спостерігати їх певну наступність. Одні автори вважають, що це біосоціальна категорія, «яка інтегрує уявлення про певний тип життя людини і характеризується іiі трудовою діяльністю, побутом, формою задоволення матеріальних і духовних потреб, правилами індивідуальної й соціальної поведінки» (Степанов, Изуткин, 1981, с. 35; Вайнер, Кастюнин, 2003; Лисицын, 1982; Попов, 1998; Федько, 2009). Як у цьому контексті зазначає О. Федько, «спосіб життя - це «обличчя» індивіда, і в той же час відображення рівня суспільного прогресу» (Федько, 2009, с. 372).

Інший підхід полягає в розгляді способу життя як «інтегрального способу буття індивіда в зовнішньому та внутрішньому світі», як «система взаємин людини із самою собою й факторами зовнішнього середовища» ${ }^{1}$.

Заслуговують на увагу напрацювання В. Ядова, який установив взаємозв'язок між соціологічним і соціально-психологічним підходами до вивчення способу життя, що дає уявлення про «співвідношення об’єктивних умов та суб’єктивних факторів життєдіяльності» (Ядов, 1983).

Важливим для концептуалізації поняття «спосіб життя» $є$ визначення Н. Паніної, котра цей конструкт розглядає як «нормативну, реальну й ідеальну структуру видів діяльності та способів їх виконання, а також психологічний стан, що включає соціальне самопочуття й психологічне здоров'я» (Панина, 2008, с. 26).

Отже, стає очевидним той факт, що розробка теоретичного супроводу феномену «спосіб життя» протягом другої половини XX - початку XXI ст. мігрувала від макросоціальних аспектів до міксування макро- та мікросоціальних контекстів життєдіяльності людини. Але важливим $є$ питання стосовно стабільності такої тенденції в сьогоденні.

Спираючись на традиції, у соціологічному словнику визначено спосіб життя (анг. way of living) як «спосіб, форми й умови індивідуальної та колективної життєдіяльності людини (трудової, побутової, соціально-політичної й культурної), типові для конкретно-історичних соціально-економічних відносин» (див.: Образ жизни_в (Antinazi)). Тож спосіб життя людини формується відповідно до тих норм, цінностей, що генералізовані в конкретному суспільстві (Возьмітель, Осадча, 2009). Іншими словами, спосіб життя «відбиває повсякденне життя соціальних груп та індивідів у ії інтегративності з погляду прояву й породження в ній соціально типового»².

Як визначає О. Мурадян, «спосіб життя» - це «сукупність сталих суспільних практик соціального суб'єкта (індивіда, групи, суспільства), у яких здійснюється його взаємозв'язок із соціальною системою (або системами соціальної дії, за Т. Парсонсом) та іншими суб'єктами в межах певної культури й проміжку часу, а також реалізуються суб'єктивно визначені життєві потреби» (Мурадян, 2012, с. 83).

${ }^{1}$ Долинский, Г. К. (1997). К понятийному аппарату валеопсихологии. Здоровье и образование. Педагогические проблемы валеологии. Материалы 2 Всерос. (с междунар. участием) науч.-практ. конф. 25-27 марта 1997 г. Санкт-Петербург, 54-56.

${ }^{2}$ Словарь терминов по модулю «Город как социальная система» Получено 05.01.2020 c http://voluntary.ru/slovari/slovar-terminov-po-modulu-gorod.html 
Узагальнюючи різноманітні визначення поняття «спосіб життя» сучасними науковцями, зауважимо, що в трактуванні способу життя простежено такі ключові маркери, як набір видів життєдіяльності, способів їх виконання, які детермінуються колом факторів макро-, мезо- та мікрорівня й відбиваються не лише на соціальних, а й психологічних параметрах життєдіяльності особистості. Отже, застосування категорії «спосіб життя» під час соціологічного аналізу, у тому числі й індивідуального здоров'я, передбачає акцентування уваги на індивідуалізованих практиках лише крізь їх приналежність до соціальної нормативної конструкції. Але в умовах соціальних змін, які динамічно народжують різноманіття соціальних практик, видів діяльності, підкорених домінанті індивідуалізму, актуальності набувають також інші акценти аналізу життя особистості. Саме тому в науковому обігу поряд із поняттям «спосіб життя» активно використовують поняття «стиль життя».

Як наукову категорію поняття «стиль життя» найчастіше соціологи пов'язують з ім'ям М. Вебера, який розглядав його як критерій соціальної стратифікації. Учений писав, що «стратифікація суспільства визначається не лише економічними й політичними, але й соціальними показниками (звички, цінності, уподобання тощо), що, урешті-решт, інтегрує певну соціальну групу та перешкоджає переходу особи до інших груп〉 (Вебер, 1994).

Інші погляди на сприйняття поняття «стиль життя» представлено в роботах Г. Зіммеля, Т. Веблена, П. Бурдьє, О. Тоффлера тощо. Зокрема, Т. Веблен й У. Уорнер пов’язували стиль життя людей із їх класовою приналежністю, О. Тоффлер - із наявністю різних субкультур (типів культур), Г. Зіммель - «соціальних типів». П. Бурдье визначав «стиль життя», застосовуючи категорії «соціальний простір» та «габітус». На його думку, «стиль життя відображає єдину інтенцію різних соціальних практик, інтеріоризованих габітусом агентів, що належать до одного й того самого класу» (Бурдье, 1998, с. 48). Іншими словами, під стилем життя науковець розумів «позиції індивіда в соціальному просторі, що визначаються через його практики та пов'язані 3 класом, до якого належить» (Бурдье, 1998, с. 48).

В енциклопедії соціології життєвий стиль (англ. Life style; нім. Lebensstil) розглянуто як «сукупність зразків поведінки індивіда або групи (стійко відтворювані риси, манери, звички, смаки, схильності), що орієнтовані переважно на повсякденне життя» (див: Стиль жизни в (Antinazi)).

Щодо сучасних соціологічних поглядів на цей феномен, то заслуговують на увагу декілька наукових традицій. Так, когорта науковців (наприклад Я. Рощина, А. Сафарян, Т. Пилаєва, Н. Масленцева) трактують стиль життя в контексті соціальної спрямованості індивіда, що зумовлює його поведінкові патерни (Рощина, 2016; Сафарян, 2008; Масленцева, 2010; Пылаева, 2009). Так, Т. В. Пилаєва визначає сутність категорії «стиль життя» як «посередництво між соціальним світом та соціальним суб'єктом» (Пылаева, 2009, 87).

Інші науковці, зокрема Н. Паніна, М. Шульга, О. Мурадян, С. Панченко, основою стилю життя вважають ціннісно-нормативні чинники, як-от: цілі, цінності, потреби, інтереси, уподобання, що проявляються під час контакту з оточенням. На думку Н. Паніної, стиль життя формується та коригується через безпосередній вплив нормативної моделі поведінки, що, з одного боку, визначається суспільною свідомістю, а з іншого - індивідуальними вподобаннями, котрі конкретизуються в життєвих планах і цілях особистості - особистісній життєвій перспективі (Панина, 2008). Зважаючи на це, «стиль життя» особистості розглядають як відображення індивідуального в соціальному (Панченко, 2008).

Із наукового погляду, інтерес становить і третій напрям досліджень цього феномену, що зумовлений особливостями сучасного суспільства. У його рамках стилю життя крізь призму стрімких і глобальних змін у суспільстві та світі загалом стосуються роботи Е. Гідденса, І. Інглхарда, Е. Тоффлера. Спираючись на їхні теоретичні висновки, можемо стверджувати, що ті зміни, котрі відбуваються в українському суспільстві, призводять до суттєвих змін у ціннісних орієнтаціях, мотивах, переконаннях, що зумовлює зміну поведінки і, як наслідок - життєвого стилю.

Детальний аналіз соціологічних поглядів на стиль життя проведено українською дослідницею О. Пахолок. Вона виокремила основні акценти в інтерпретації цього поняття (Пахолок, 2014): стиль життя як відображення позиції індивіда в соціальній структурі та його становище в соціальному просторі; стиль життя як продукт процесу соціалізації та відображення культури; стиль життя як реалізація внутрішнього особистісного локус-контролю індивіда. Такі узагальнення, на нашу думку, 
дають підставу стверджувати, що використання категорії «стиль життя» можливе на різних рівнях соціальної динаміки - від макро- до мікрорівня.

Наш аналіз свідчить, що існують також і інтегрувальні визначення стилю життя. Наприклад, О. Г. Малина трактує його як «структуру, що забезпечує варіативність життєдіяльності людей у суспільстві»; виступає формою самопрояву, самоствердження й самовдосконалення особистості та визначається як особливий індивідуальний спосіб реалізації особистістю обраного нею життєвого шляху, індивідуально своєрідна цілісна система стійких засобів і «форм опосередкування особистістю об'єктивних умов життєдіяльності, яка формується на основі потреб та здібностей і проявляється в процесі реалізації життєвої мети та планів особистості» (Малина, 2009).

Загалом, потрібно підкреслити, що в соціологічних інтерпретаціях стилю життя важливою постає певна «вбудованість» індивідуальних особливостей людини в соціальній простір (через норми, статус, цінності). Але зазначимо, що сприйняття цього феномену не однозначне й часто розглядається у співвідношенні з категорією «спосіб життя». Так, у наукових джерелах існує три підходи до співвіднесення понять «стиль життя» та «спосіб життя». Представники першого застосовують поняття «спосіб життя» як синонім до терміна «стиль життя» (Рощина, 2007, с. 135). Більшість науковців розглядають категорію «стиль життя» в більш вузькому розумінні, ніж «спосіб життя». Проте в працях учених простежено ще й третій підхід щодо визначення концепту «стиль життя» - його розмежовують із поняттям «спосіб життя», оскільки обидва поняття однаковою мірою відображають моделі організації життя особистості, але на різних рівнях.

Як результат, дослідницькі лінії стосовно потенціалу понять «спосіб життя» та «стиль життя» протягом останнього часу досить наблизились одна до одної, але не злилися в один потік. Можемо стверджувати, що поняття «стиль життя» відображає вибір особистістю тих чи інших варіантів реалізації соціальних практик, а іноді й власне конструювання цих варіантів. Можливості такого вибору є більш широкими, порівняно зі способом життя, який має певні соціальні рамки.

Поглянемо на позначений вище потенціал «способу життя» та «стилю життя» для отримання відповіді на питання, яке 3 них і в якому контексті є більш доречним для дослідження феномену індивідуального здоров'я.

Порівняльний аналіз понять «спосіб життя» й «стиль життя» дає підставу зробити такі висновки:

- суб'єктом стилю життя є окрема особистість із характерними для неї вподобаннями, ціннісними орієнтаціями, життєвими потребами, звичками, манерами, схильностями, мотивами тощо, яка різними засобами «реалізує ззовні свою цілісну індивідуальність», обирає власну стратегію поведінки. Зі свого боку, суб'єктом способу життя є суспільство або великі соціальні групи, котрі генерують соціально-типові форми життєдіяльності; носіями рис яких виступає індивід, тож спосіб життя «нав'язує індивідам певну соціокультурну ідентичність». Отже, під час дослідження соціальних груп більш прийнятним буде поняття «спосіб життя», а стосовно особистості чи невеликих угрупувань - «стиль життя», оскільки такі дослідження передбачають занурення науковця в повсякденність об'єкта;

- стиль життя передбачає варіативність вибору в межах соціально можливих варіантів («життєвих шансів»), проте спосіб життя - обмеження, які суспільство накладає на індивіда, або, іншими словами, обрання індивідом чітко регламентованих (необхідних i типових) практик (еталонну модель);

- стиль життя - «типовий вибір у рамках можливого», а спосіб життя - необхідність, «вийти за рамки якої можна, лише покинувши межі поля, що породило відповідні форми життєдіяльності»;

- стиль життя є однією 3 динамічних категорій способу життя, завдяки котрій спосіб життя реально втілюється в дійсність через індивідуальність особистості;

- стиль життя $\epsilon$ однією з найбільш динамічних складових частин способу життя, що здатен змінюватися під впливом як об’єктивних умов, так і «внутрішніх спонукальних сил».

Використовуючи зазначені лінії порівняння, для досягнення нашої мети здійснимо аналіз можливостей застосування понять «спосіб життя» й «стиль життя» для розгляду феномену здоров'я людини. Ідеться про «здоровий спосіб життя» та «здоровий стиль життя». У першому аспекті в наукових джерелах наведено різні тлумачення поняття «здоровий спосіб життя» (див., наприклад, Боженова, Трошкін, 2016), проте єдиного загальноприйнятого визначення немає. Зокрема, у сфері соціальної 
політики здоровий спосіб життя визначено як «активну діяльність людей, спрямовану на збереження та зміцнення здоров'я як умови і передумови здійснення інших аспектів способу життя, на подолання чинників ризику виникнення і розвитку захворювань, оптимального використання і в інтересах охорони i поліпшення здоров'я, соціальних і природних умов та чинників способу життя» (Головатий, Панасюк, 1997, с. 174); як «спосіб життєдіяльності людини, який вона усвідомлено обирає і відповідально відтворює в повсякденному бутті з метою збереження та зміцнення здоров'я, як продукт духовних і фізичних зусиль людини, цілісна система життєвих проявів особистості, що сприяє гармонізації іiі індивідуальності в умовах соціального середовища» (Енциклопедія для фахівців..., 2012, с. 51-52); як «спосіб життєдіяльності людини, метою якого є формування, збереження і зміцнення здоров'я» (Все про соціальну роботу, 2012, с. 174).

Представники медичної наукової спільноти трактують «здоровий спосіб життя» як спосіб життедіяльності, відповідний генетично обумовленим типологічним особливостям певної людини, конкретних умов життя й спрямований на формування, збереження та зміцнення здоров'я й виконання людиною іï соціально-біологічних функцій (Артюнина, 2009), як максимальну кількість біологічно та соціально доцільних форм і способів життєдіяльності, адекватних потребам і можливостям людини, усвідомлено реалізованих нею, що забезпечують формування, збереження й зміцнення здоров'я, здатність до продовження роду та досягнення активного довголіття (Колбанов, 1998).

У педагогічному колі актуальне визначення здорового способу життя як сукупності таких умов навчання й виховання, у яких формуються та проявляються звички, соціальні практики, котрі сприяють збереженню, зміцненню, відтворенню здоров'я. Е. Н. Вайнер визначає здоровий спосіб життя як «спосіб життєдіяльності, який відповідає генетично обумовленим особливостям конкретної людини, конкретним умовам життя і спрямований на формування, збереження та зміцнення здоров'я, на повноцінне виконання людиною його соціально-біологічних функцій» (Вайнер, 2001, с. 201).

Психолого-педагогічне тлумачення категорії «здоровий спосіб життя» полягає в сприйнятті його як «якоїсь еталонної моделі, системи загальних умов, приписів, заходів, сукупності подібного, але не тотожного, продукту колективної творчості» (Виленский, Авчинникова, 2004).

Із погляду психології, здоровий спосіб життя - це «комплекс раціональних поведінкових правил, що гарантують індивіду максимальний захист від чинників ризику навколишнього середовища, які мають негативний вплив на нього» (Волошко, 2011, с. 117).

У рамках соціологічного знання «здоровий спосіб життя» розглядають як прояв реалізації потенціалу суспільства (в індивідуальних або групових проявах) у забезпеченні здоров’я. Також він відображає міру соціального благополуччя, що розуміється як єдність рівня і якості життя (Социология: энциклопедия).

Застосування концепту «спосіб життя» під час дослідження феномену здоров'я дає підставу говорити про те, здоровий спосіб життя розглядається в міждисциплінарному ракурсі як певна стратегія, сукупність типізованих практик, спрямованих на збереження та підтримку здоров'я, що має суспільну цінність і значущість для виконання соціальних ролей та функцій.

Але аналіз наукових джерел із питань здорового способу життя свідчить, що деякі дослідники його розглядають крізь призму стилю поведінки, «який приводить людину до бажаної тривалості й необхідної якості життя» (Загрутдинова, 2014). Із такої позиції здоровий стиль життя трактують як «індивідуалізований варіант відповідного способу життя, що включає в себе світоглядний, поведінковий і діяльнісний аспекти» (Виленский, Авчинникова, 2004, с. 297).

У зарубіжних наукових джерелах розглянуто також категорію «стиль життя відносно здоров'я». Так, У. Кокерхейм визначив стиль життя по відношенню до здоров'я як «колективні моделі поведінки в ставленні до здоров'я, що є результатом індивідуального вибору можливостей, які вони мають у своєму розпорядженні відповідно до їхньої позиції в соціальній структурі» (Cockerham, 2005, p. 54).

Представники української валеологічної школи, зокрема Т. Парфіненко, розглядають «стиль життя у площині здоров'я» як систему повторюваних у повсякденній поведінці «здорових» чи «нездорових» практик, що визначають становище людини в соціальному просторі (Парфіненко, 2015). Тож здоровий життєвий стиль зумовлений вибором саме оптимальних (здорових) практик. 
Становить науковий інтерес розгляд концепту стилю життя в контексті осмислення феномену «здорового способу життя» О. Пахолок. Вона підкреслює, що, стосовно того, що здоровий стиль життя передбачає систему індивідуальних потреб (зокрема в самоактуалізації), які сприяють розвитку особистості, гармонізації ії індивідуальності, та способи реалізації цих потреб, то можемо зробити висновок, що «здоровий стиль життя» $є$ характеристикою індивідуальною. Проте, як зазначає дослідниця, його прояви мають відображення на різних рівнях взаємодії - на рівні мікро-, мезо- та екзосистем (Пахолок, 2011).

Отже, стає очевидним той факт, що здоровий стиль життя зумовлений індивідуальними особливостями здоров'я людини і її потребами в підтримці такого або іншого стану індивідуального здоров'я. Відповідно, здоровий спосіб життя дає підставу порівнювати практики щодо власного здоров'я з погляду їх типовості, відповідності соціальним уявленням про них тощо.

Висновки. Отже, розмежування понять «здоровий спосіб життя» - «здоровий стиль життя» можна здійснювати в площині протистоянь «норма» - «варіативність», «заданість» - «індивідуальність». Вони різняться як за обсягом, так і за характером, соціальними функціями, суб'єктом явищ і процесів, які вони віддзеркалюють. Зважаючи на це, категорію «здоровий стиль життя» визначимо як субкатегорію «здорового способу життя» й позначимо превалювання останньої під час досліджень індивідуального здоров'я. При цьому «здоровий спосіб життя» - це певна соціально детермінована модель, система загальних соціально-політичних, культурних, соціально-економічних умов, котрі визначають колективні зразки поведінки, орієнтованої на збереження та зміцнення здоров'я на основі соціальних виборів, доступних для соціальних суб'єктів певного суспільства. Вони мають значення для суспільства в цілому, оскільки застосовують єдині критерії індивідуального здоров'я до всіх членів суспільства.

Зазначимо, що використання цього поняття допускає варіативність і мультиакцентність. Тобто вибір концепту «спосіб життя» для дослідження феномену здоров'я не надає проблематиці рис універсальності та монотрактувань. При цьому потрібно мати на увазі той факт, що в практичній площині сьогодні існують досить спрощені індикатори оцінки способу життя, націленого на збереження здоров'я. У зв'язку з цим здійснюється пошук нових підходів до аналізу процесів формування здорового способу життя (health promotion) особистості.

\section{Джерела та література}

1. Артюнина, Г. П. (2009). Основь медицинских знаний и здорового образа жизни. Москва: Академический проект; Фонд «Мир».

2. Боженова, А. С., Трошкін, Е. І. (2016). Структура та теоретичні основи поняття «здоровий спосіб життя». Політичний вектор-A, 1-2, 156-158.

3. Бурдье, П. (1998). Структура, габитус, практика. Журнал соџиологии и социальной антропологии, 1(2), 44-59.

4. Вайнер, Е. Н. (2001). Валеология. Москва: Наука.

5. Вайнер, Э. Н., Кастюнин, С. А. (2003). Краткий энцииклопедический словарь: Адаптивная физическая культура. Москва: Флинта.

6. Вебер, М. (1994). Основные понятия стратификации. Социологические исследования, 5, 146-156.

7. Виленский, М. Я., Авчинникова, С. О. (2004). Методологический анализ общего и особенного в понятиях «здоровый образ жизни» и «здоровый стиль жизни». Теория и практика физической культуры, 11, 2-7.

8. Возьмитель, А. А., Осадча, Г. И. (2009). Способ жизни: теоретико-методологические основы анализа. Социологические исследования, 8, 58-65.

9. Возьмитель, А. А. (2012). Образ жизни: тенденщии и характер изменений в пореформенной России. Москва: Ин-т социологии РАН.

10. Возьмитель, А. А. (2017). Реконцептуализация социологического подхода к изучению способа жизни. Вестник Нижегородского университета им. Н. И. Лобачевского. Серия: Социальные науки, 4(48), 55-64.

11. Волошко, Н. І. (2011). Детермінанти ставлення до здоров'я і здорового способу життя. Проблеми сучасної психологіï, 11, 115-124.

12. Все про соціальну роботу (2012): навч. енцикл. слов.-довід./за заг. ред. В. М. Пічі. Львів: «Новий Світ2000».

13. Головатий, М. Ф., Панасюк, М. Б. (1997). Соціальна політика і соціальна робота: Термінол.-понят. слов. Київ: МАУП. 
14. Енциклопедія для фахівичів соиіальної сфери (2012). За заг ред. проф. І. Д. Звєрєвої. Київ; Сімферополь: Універсум.

15. Журавлева, И. В. (2002). Здоровье подростков: сочииологический анализ. Москва: Изд-во Ин-та социологии РАН.

16. Загрутдинова, А. Г. (2014). Здоровье подростков в трансформирующзейся России: соичиологический анализ (на материалах республики Татарстан). Дис. ... канд. соц. наук: 14.02.05. Волгоград.

17. Колбанов, В. В. (1998). Валеология: основные понятия, термины и определения. Санкт-Петербург: ДЕАН.

18. Лисицын, Ю. П. (1982). Образ жизни и здоровье населения. Москва: Знание, 65.

19. Малина, О. Г. (2009). Психологічні особливості становлення стилю життя особистості в підлітковому і юнацькому віці. Автореф. дис. на здобуття наук. ступеня канд. психол. наук: 19.00.07. Київ.

20. Маркс, К., Енгельс, Ф. (1955). Немеикая идеология. Избранные трудыл. Москва: Полит. лит., т. 1 - тв., T. 3.

21. Масленцева, Н. Ю. (2010). Социологические основания концепции стиля жизни. Вестник ЧелГУ, 31, $147-$ 150. Получено 6 января 2020 c https://cyberleninka.ru/article/n/sotsiologicheskie-osnovaniya-kontseptsii-stilyazhizni

22. Мурадян, О. С. (2012). Спосіб життя як система соціальної дії: спроба концептуалізації. Соціологічні cmyдï, 1, 81-87.

23. Панченко, С. (2008). Еволюція категорії «стиль життя» в соціології. Стилі життя: панорама змін. Київ: Ін-т соціології НАН України, 11-24.

24. Панина, Н. В. (2008). Избранные труды по социологии. [В 3 т.]. Т. II: Теория, методы и результаты соииологического исследования образа жизни, психологического состояния и сочиального самочувствия населения. Киев: Факт.

25. Парфіненко, Т. О. (2015). Підходи до визначення сутності та структури поняття «здоровий стиль життя». Матеріали XIII міжнар. наук.-прак. конф. «Валеологія: сучасний стан, напрямки та перспективи розвитку», м. Харків, 9-11 трав. 2015. Харків: ХНУ ім. В. Н. Каразіна. 46-48. Отримано 4 січня 20203 http://dspace.univer.kharkov.ua/bitstream/123456789/12577/2/n40-45-48.pdf

26. Парфенова, А. А., Проскурнина, М. В., Цой, В. С. (2020). Образ жизни и здоровье человека. Онлайн библиотека «Наука и философия». Получено 04 января 2020 c http://tomb-raider6.narod.ru/lib/mm/ materialy_vtorogo_mezhdunarodnogo/obraz_zhizni_i_zdorove_cheloveka.html

27. Пахолок, О. (2011). Орієнтація на здоровий спосіб життя: до проблеми логічної формалізації об’єкта дослідження. Соціальні виміри суспільства, 3, 187-197.

28. Пахолок, О. О. (2014). Феномен здоров'я в сочіокультурному вимірі. Автореф. канд. соціол. наук, спец.: 12.00.01 - теорія та історія соціології. Київ: Ін-т соціології НАН України.

29. Попов, С. В. (1998). Валеология в школе и дома. О физическом благополучии школьников. СанктПетербург: Союз. 253 с.

30. Пылаева, Т. В. (2009). Стили жизни студенческой молодежи: типология и детерминанты формирования. Дис. ... канд. социол. наук: 22.00.04. Харків, 187 с.

31. Рощина, Я. М. (2007). Социология потребления. Москва: Издат. дом «ГУ-ВШЭ».

32. Рощина, Я. М. (2016). Стиль жизни в отношении здоровья: имеет ли значение социальное неравенство? Экономическая социология, 17(3), 13-34.

33. Сафарян, А. В. (2008). Стиль жизни. Энцииклопедия гуманитарных наук. 1, 246-248. Получено 5 января

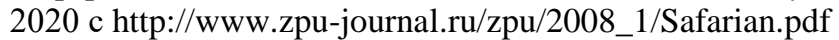

34. Советский образ жизни: состояние, мнения и оценки советских людей (1984). Под ред. И. Т. Левыкина и А. А. Возьмителя. Москва: ИСИ.

35. Социология: Энциклопедия. Сост. А. А. Грицанов, В. Л. Абушенко, Г. М. Евелькин, Г. Н. Соколова, О. В. Терещенко. Получено 16 декабря 2019 с http:/voluntary.ru/dictionary/568/word/zdorovyi-obrazzhizni.

36. Степанов, А. Д., Изуткин, Д. А. (1981). Критерии здорового способа жизни и предпосылки его формирования. Советское здравоохранение, 5, 32-44.

37. Федько, О. (2009). Здоровий спосіб життя як цінність: проблеми формування. Наукові записки Інституту політичних і етнонаціональних досліджень ім. І. Ф. Кураса НАН Украӥни, 43, 369-379.

38. Ядов, В. А. (1983). Социологический поход к исследованию личности в системе понятий образа жизни. Вопросы философии, 12.

39. Яковлева, Н. В. (2013). Здоровьесберегающая деятельность как базовый жизненный метапроцесс. Сетевой журнал, 1, 56-64.

40. Antinazi. Энщиклопедия социологии (2009). Словари и энциклопедии на Академике. Получено 14 декабря 2019 с https://dic.academic.ru/dic.nsf/socio/ 
41. Cockerham, W. C. (2005). Health lifestyle theory and the convergence of agency and structure. The Journal of Health and Social Behavior, 46(1), 51-67. https://doi.org/10.1177/002214650504600105

42. WHO strategy on research for health. Geneva, World Health Organization, 2016. Retrieved April 23, 2019 from http://www.who.int/phi/WHO_Strategy_on_research_for_health.pdf

\section{References}

1. Artyunina, G. P. (2009). The basics of medical knowledge and a healthy lifestyle. Moscow: Academic Project; Foundation «Mir».

2. Antinazi. Encyclopedia of Sociology (2009). Dictionaries and Encyclopedias on the Academician. Retrieved December 14, 2019 from http://dic.academic.ru/dic.nsf/socio/

3. Bourdieu, P. (1998). Structure, habit, practice. Journal of Sociology and Social Anthropology, 2(1), 44-59.

4. Bozhenova, A. S., Troshkin, E. I. (2016). The structure and the theoretical basis of the concept of «healthy way of living». Political vector-A, 1-2, 156-158.

5. Cockerham, W. C. (2005). Health lifestyle theory and the convergence of agency and structure. The Journal of Health and Social Behavior, 46 (1), 51-67. https://doi.org/10.1177/002214650504600105

6. Everything about the social work (2012): primary encyclopedic vocabulary-dictionary / ed. by V. M. Picha. Lviv: «New Svit-2000».

7. Fedko, O. (2009). Healthy way of life as a value: problems of formation. Scientific notes of Institution of political and etnonations research, 43, 369-379.

8. Golovatiy, M. F., Panasyuk, M. B. (1997). Social policy and social work: glossary of words. Kyiv: IAPM.

9. Kolbanov, V. V. (1998). Valeology: basic concepts, terms and definitions. Sankt-Peterburg: DEAN.

10. Lisitsyn, Yu. P. (1982). Lifestyle and public health. Moscow: Knowledge.

11. Malyna, O. G. (2009). Psychological peculiarities of becoming a style of life of person in children's and youth's age. Abstract. Kyiv.

12. Marx, C., Engels, F. (1955). German ideology. Selected Works. Moscow: Political literature. Vol. 1, Vol. 3.

13. Maslentseva, N. Yu. (2010). Sociological basis of the concept of lifestyle. Bulletin of ChelSU. 31, $147-150$. Received January 06, 2020 from https://cyberleninka.ru/article/n/sotsiologicheskie-osnovaniya-kontseptsiistilya-zhizni

14. Muradyan, O. S. (2012). The way of life as a system of social act: a test of conceptualization. Sociological Studios, 1, 81-87.

15. Paholok, O. (2011). Organization for a healthy way of life: to the problem of logical formalization of research subject. Social measurement of society, 3, 187-197.

16. Pakholok, O. O. (2014). The phenomenon of health in social and cultural measurement: abstract. Kyiv: Institute of Sociology, NAS of Ukraine.

17. Panchenko, S. (2008). Evolution category «life style» in social science. Life styles: panorama of changes. Kyiv: Institute of Sociology of the National Academy of Sciences of Ukraine, 11-24.

18. Panina, N. V. (2008). Theory, methods and results of a sociological study of the lifestyle, psychological state and social well-being of the population. Selected works on sociology, Vol. II: Kyiv: Fact.

19. Parfenova, A. A., Proskurnina, M. V., Tsoi, V. S. (2020). Mode of life and human health. Online library «Science and Philosophy». Retrieved January 04, 2020 from http://tomb-raider6.narod.ru/lib/mm/materialy_ vtorogo_mezhdunarodnogo/

20. Parfinenko, T. O. (2015). Become to the current day and the structure of the understanding «healthy life style». Retrieved January 04, 2020 from http://dspace.univer.kharkov.ua/bitstream/123456789/12577/2/n4045-48.pdf

21. Popov, S. V. (1997). Valeology at school and at home. About the physical well-being of schoolchildren. Sankt-Peterburg: «Soyuz».

22. Pylaeva, T. V. (2009). Lifestyle of students: typology and determinants of formation: thesis. Kharkiv.

23. Roshchina, Y. M. (2007). Sociology of consumption. Moscow: Publishing house «SU-HSE».

24. Roshchina, Y. M. (2016). Health lifestyle: Does social inequality matter? Economic Sociology, 17(3), $13-34$.

25. Safaryan, A. V. (2008). The concept of life style in sociology. Retrieved January 05, 2020 from http://www.zpu-journal.ru/zpu/2008_1/Safarian.pdf

26. Sociology: Encyclopedia / Comp. A. A. Gritsanov, V. L. Abushenko, G. M. Evelkin, G. N. Sokolova, O. V. Tereshchenko. Retrieved December 16, 2019 from http://voluntary.ru/dictionary/568/word/zdorovyiobraz-zhizni.

27. Soviet way of life: state, opinions and assessments of Soviet people (1984). Ed. by I. T. Levykina and A. A. Vozmitel. Moscow: ISI.

28. Stepanov, A. D., Izutkin, D. A. (1981). Criteria for a healthy way of living and the background of its formation. Soviet health care, 5, 32-44. 
29. The Encyclopedia for the Social Sphere specialists (2012). Ed. by prof. I. D. Zvereva. Kyiv-Simferopol: Universum.

30. Vilensky, M. Ya., Avchinnikova, S. O. (2004). A methodological analysis of the general and the special in the concepts of «healthy way of living» and «healthy lifestyle». Theory and Practice of Physical Culture, 11, 2-7.

31. Voloshko, N. I. (2011). Determinants posed to a healthy and healthy way of life. Problems of a modern psychology, 11, 115-124.

32. Vozmitel, A. A., Osadcha, G. I. (2009). Way of life: theoretical and methodological foundations of analysis. Sociological studies, 8, 58-65.

33. Vozmitel, A. A. (2012). Way of living: trends and the nature of changes in post-reform Russia. Moscow: Institute of Sociology RAS.

34. Vozmitel, A. A. (2017). Reconceptualization of the sociological approach to the study of the way of life. Bulletin of the Nizhny Novgorod University of N. I. Lobachevsky. Series: social sciences, 4 (48), 55-64.

35. Weber, M. (1994). The basic concepts of stratification. Sociological studies, 5, 146-156.

36. Weiner, E. N. (2001). Valeology. Moscow: Science.

37. Weiner, E. N., Kastyunin, S. A. (2003). Brief Encyclopedic Dictionary: Adaptive Physical Culture. Moscow: Flinta.

38. WHO strategy on research for health. Geneva, World Health Organization, 2016. Retrieved April 23, 2019 from http://www.who.int/phi/WHO_Strategy_on_research_for_health.pdf

39. Yadov, V. A. (1983). A sociological approach to the study of personality in the system of concepts of mode of life. Questions of Philosophy, 12.

40. Yakovleva, N. V. (2013). Health saving activity as a basic life metaprocess. Network Journal, 1, 56-64.

41.Zagrutdinova, A. G. (2014). Adolescent health in a transforming Russia: a sociological analysis (based on materials from the Republic of Tatarstan): thesis. Volgograd.

42. Zhuravleva, I. V. (2002). Adolescent Health: A Sociological Analysis. Moscow: Publishing House of the Institute of Sociology of the Russian Academy of Sciences. 